\title{
The Efficiency of Carbon Dioxide and Hydrogen Sulphide Adsorption using Impregnated Granular Activated Carbon and Zeolite
}

\author{
Rewadee Anuwattana, ${ }^{1 *}$ Pattamaphorn Phungngamphan ${ }^{1}$ and \\ Petchporn Chawakitchareon ${ }^{2}$
}

\author{
${ }^{1}$ Expert Centre of Innovative Clean Energy and Environment, \\ Thailand Institute of Scientific and Technological Research, Pathumthani 12120, Thailand \\ ${ }^{2}$ Department of Environmental Engineering, Faculty of Engineering, \\ Chulalongkorn University, Bangkok 10330, Thailand
}

*Corresponding author: rewadee_a@tistr.or.th

Published online: 25 October 2018

To cite this article: Anuwattana, R., Phungngamphan, P. \& Chawakitchareon, P. (2018). The efficiency of carbon dioxide and hydrogen sulphide adsorption using impregnated granular activated carbon and zeolite. J. Phys. Sci., 29(Supp. 3), 29-36, https://doi.org/10.21315/ jps2018.29.s3.4

To link to this article: https://doi.org/10.21315/jps2018.29.s3.4

\begin{abstract}
In this work, adsorbents granular activated carbon (GAC), granular activated carbon with acetylene $(C V D / G A C)$ and zeolite $A$ were applied for carbon dioxide $\left(\mathrm{CO}_{2}\right)$ and hydrogen sulphide $\left(\mathrm{H}_{2} \mathrm{~S}\right)$ gas removal. The adsorbents were characterised by scanning electron microscope (SEM) and X-ray diffraction (XRD). Polyethyleneimine (PEI) in ethanol with initial concentration of $0.2 \mathrm{~g} \mathrm{l}^{-1}$ and $1 \mathrm{~mol} \mathrm{dm^{-3 }}$ lithium nitrate $\left(\mathrm{LiNO}_{3}\right)$ were prepared to improve the adsorption capacity. In the impregnation process, various adsorbents, i.e., GAC, CVD/GAC and zeolite A were placed in a vial containing $0.2 \mathrm{~g} \mathrm{l}^{-1}$ of $P E I$ and $1 \mathrm{~mol} \mathrm{dm}^{-3}$ of $\mathrm{LiNO}_{3}$ solution, at different ratios of adsorbent and various solutions of 30\%W/W. The adsorbents (GAC, PEI/CVD/GAC:PEI/GAC, LiNO $3 / C V D / G A C: \mathrm{LiNO}_{3} /$ GAC, zeolite $5 \mathrm{~A}, \mathrm{PEI} / \mathrm{zeolite} 5 \mathrm{~A}$ and $\mathrm{LiNO}_{3} /$ zeolite $\left.5 \mathrm{~A}\right)$ were tested by using the synthetic biogas $\left(45 \% \mathrm{CO}_{2}, 10 \% \mathrm{~N}_{2}, 45 \% \mathrm{CH}_{4}\right.$ and $105 \mathrm{mg} \mathrm{dm}^{-3}$ of $\left.\mathrm{H}_{2} \mathrm{~S}\right)$. The performance of $\mathrm{CO}_{2}$ and $\mathrm{H}_{2} \mathrm{~S}$ adsorption results have shown that PEI/CVD/GAC is the best adsorbent for low concentration of $\mathrm{H}_{2} \mathrm{~S}$ and $\mathrm{LiNO}_{3} / 5 \mathrm{~A}$ is the best adsorbent for $\mathrm{CO}_{2}$ adsorption. The purity of the outlet methane was $96.6 \%, 97.3 \%, 98.1 \%, 81.53 \%, 80.6 \%$ and $93.6 \%$ for zeolite $5 \mathrm{~A}$, $\mathrm{LiNO}_{3} / 5 \mathrm{~A}, \mathrm{PEI} / 5 \mathrm{~A}, \mathrm{GAC}, \mathrm{LiNO}_{3} / \mathrm{CVD} / \mathrm{GAC}$ and PEI/CVD/GAC, respectively. The selectivity in the $\mathrm{H}_{2} \mathrm{~S} / \mathrm{CH}_{4}$ ratio of $\mathrm{GAC}$ is higher than zeolite $5 \mathrm{~A}$. The adsorption selectivity of the $\mathrm{CO}_{2} /$ $\mathrm{CH}_{4}$ ratio of $\mathrm{LiNO}_{3} / 5 \mathrm{~A}$ is higher than $\mathrm{GAC}$.
\end{abstract}

Keywords: Activated carbon, zeolite A, polyethyleneimine chemical vapour deposition granular activated carbon, carbon dioxide adsorption, hydrogen sulphide adsorption 


\section{INTRODUCTION}

Biogas is produced from anaerobic degradation of organic materials. It is a mixture composed of approximately 50\%-70\% $\mathrm{CH}_{4}, 30 \%-50 \%$ carbon dioxide $\left(\mathrm{CO}_{2}\right)$, smaller amounts of $\mathrm{NH}_{3}(80-100 \mathrm{ppm})$, hydrogen sulphide $\left(\mathrm{H}_{2} \mathrm{~S}, 500-1,000 \mathrm{ppm}\right)$ and hydrocarbon $(<100 \mathrm{ppm}) .{ }^{1}$ The advantage of biogas is that it can be used to generate electricity and heat energy. However, biogas purification is required to remove $\mathrm{CO}_{2}$ and $\mathrm{H}_{2} \mathrm{~S}$ in order to upgrade it to natural gas grade substitute for car fuel. $\mathrm{H}_{2} \mathrm{~S}$ corrodes vital mechanical components within the engine generator and vehicle engines if not removed. When burning $\mathrm{H}_{2} \mathrm{~S}$, the compound will be converted to $\mathrm{SO}_{2}$, which is a pollutant. $\mathrm{H}_{2} \mathrm{~S}$ is the foul smell inherent in wastewater treatment plants, animal processing and food processing plants. ${ }^{2}$ Removal of $\mathrm{CO}_{2}$ and $\mathrm{H}_{2} \mathrm{~S}$ using amine aqueous solution absorption has been an industrial method for decades. However, amine absorption is unfit for $\mathrm{H}_{2} \mathrm{~S}$ removal in low concentration due to loss of solution, corrosion and high cost of removal. ${ }^{3,4}$

In many research works on $\mathrm{CO}_{2}$ removal by adsorption, the adsorbents should have attributes such as being low-cost raw materials, exhibiting low heat capacity, fast kinetics, high $\mathrm{CO}_{2}$ adsorption capacity, high $\mathrm{CO}_{2}$ selectivity, and thermal and chemical stabilities over several cycling rounds. Activated carbon is the carbonaceous adsorbent which is used for $\mathrm{CO}_{2}$ adsorption because of low cost and high thermal stability. Carbon molecular sieve (CMS), which is the narrow pore size distribution of activated carbon, is a characteristic that allows high adsorption. Zhang et al. determined the adsorption capacity of activated carbon at $2.27 \mathrm{mmol} \mathrm{g}^{-1}$ at $298 \mathrm{~K}^{5}$ The amine or high oxidising agent impregnated on adsorbent will increase the rate of adsorption. Improvement of $\mathrm{CO}_{2}$ adsorption such as through polyethyleneimine (PEI) impregnation and chemical vapour deposition process can increase the adsorption capacity of granular activated carbon. Rewadee et al. conducted the preparation of CVD/GAC from coffee bean, which is an effective adsorbent for $\mathrm{CO}_{2}$ removal, and using synthetic biogas $\left(30 \% \mathrm{CO}_{2}, 20 \% \mathrm{~N}_{2} \text { and } 50 \% \mathrm{CH}_{4}\right)^{6}$

Zeolite has played a major role in the development of adsorption technology. The framework of zeolite consists of an assemblage of aluminate and silicate tetrahedral, and shared oxygen atoms to form an open crystal lattice. Zeolite molecular sieve is widely used as sorbent for gas separation due to its large surface area. The sorption process based on solid adsorbents are being actively pursued, especially using inorganic porous materials such as zeolite $13 \mathrm{X}$ and using different recycling configurations and high performance by pressure swing adsorption. Although low silica materials have high adsorption capacity and selectivity at low pressure, they are sensitive to moisture, which inhibits the $\mathrm{CO}_{2}$ adsorption. The $\mathrm{CO}_{2}$ 
adsorption capacity on zeolite $\mathrm{A}, \mathrm{X}$ and $\mathrm{Y}$ is higher than silicoaluminophosphate (SAPO) zeolite. ${ }^{7}$ Zeolite $5 \mathrm{~A}$ has been proven effective for $\mathrm{CO}_{2}$ and $\mathrm{H}_{2} \mathrm{~S}$ removal. Wang et al. produced the nanoporous composite sorbent called "molecular basket" by loading PEI on molecular sieve such as MCM41 and SBA15. ${ }^{8}$ Yong et al. produced adsorbents with strong oxidising ability, using transition metals of $\mathrm{Zn}$, $\mathrm{Cu}$ and $\mathrm{Fe}$, which have been studied for $\mathrm{H}_{2} \mathrm{~S}$ adsorption and oxidation. . $^{9-11}$ The main objective of this work is to prepare the adsorbents impregnated with $\mathrm{LiNO}_{3}$ and $\mathrm{PEI}\left(\mathrm{GAC}, \mathrm{LiNO}_{3} / \mathrm{GAC}, \mathrm{PEI} / \mathrm{GAC}\right.$, zeolite $5 \mathrm{~A}, \mathrm{LiNO}_{3} /$ zeolite $5 \mathrm{~A}$ and $\mathrm{PEI} /$ zeolite $5 \mathrm{~A}$ ), and investigate their $\mathrm{CO}_{2}$ and $\mathrm{H}_{2} \mathrm{~S}$ removal performance.

\section{EXPERIMENTAL}

\subsection{Preparation and Characterisation of Adsorbents}

Commercial granular activated carbon (GAC) was purchased from METRA Co. Ltd. It was dried at $200^{\circ} \mathrm{C}$ for $2 \mathrm{~h}$. The modified granular activated carbon or carbon molecular sieve (CMS) prepared by chemical vapour deposition on granular activated carbon (CVD/GAC) was deposited with acetylene by a chemical vapour deposition process under $15 \mathrm{ml} \mathrm{min}{ }^{-1}$ of acetylene and followed with $50 \mathrm{ml} \mathrm{min} \mathrm{m}^{-1}$ of nitrogen flow at $800^{\circ} \mathrm{C}$ for $30 \mathrm{~min}$. Zeolite $5 \mathrm{~A}$ was purchased from Thai Silicate Co. Ltd. It was crushed and screened in $325 \mu \mathrm{m}$ and dried at $200^{\circ} \mathrm{C}$ for $2 \mathrm{~h}$.

PEI with average molecular weight $100,000 \mathrm{~g} \mathrm{~mol}^{-1}$ was obtained from Sigma Aldrich. An amount of $15 \mathrm{~g}$ of PEI was dissolved in $30 \mathrm{~g}$ of ethanol with initial concentration of $0.2 \mathrm{~g} \mathrm{l}^{-1}$ under stirring for $20 \mathrm{~min}$. In the impregnation process, $10 \mathrm{~g}$ of GAC and CVD/GAC were placed in a vial containing PEI solution in the adsorbent/solution ratio of $30 \% \mathrm{w} / \mathrm{w}$. The adsorbents $(\mathrm{GAC}, \mathrm{CVD} / \mathrm{GAC}$ and zeolite 5A) with PEI loading were stirred at $120 \mathrm{rpm}$ for $3 \mathrm{~h}$. It was dried at $105^{\circ} \mathrm{C}$ overnight. The obtained products are $\mathrm{PEI} / \mathrm{GAC}, \mathrm{PEI} / \mathrm{CVD} / \mathrm{GAC}$ and $\mathrm{PEI} /$ zeolite $5 \mathrm{~A}$, respectively.

About $2 \mathrm{~g}$ of various adsorbents $\left(\mathrm{LiNO}_{3} / \mathrm{GAC}, \mathrm{LiNO}_{3} / \mathrm{CVD} / \mathrm{GAC}\right.$ and $\mathrm{LiNO}_{3} /$ zeolite $5 \mathrm{~A}$ ) was prepared by impregnation adsorbents (GAC, CVD/GAC and zeolite 5A) with $1 \mathrm{M}$ of $\mathrm{LiNO}_{3}$ in the adsorbent/solution ratio of $30 \% \mathrm{w} / \mathrm{w}$ under agitation for $60 \mathrm{~h}$ at room temperature. It was dried at $105^{\circ} \mathrm{C}$ overnight. The obtained products were washed to remove the soluble impurities off and calcinations, in order to remove volatile compounds. The final product was dried at $105^{\circ} \mathrm{C}$ overnight and kept in the desiccators. Scanning electron microscope (SEM) analysis was carried out by using JSM-6400 (JEOL, Japan). X-ray diffraction (XRD) was performed using $\mathrm{Cu}-\mathrm{K} \alpha$ radiation (Rigaku Corp., Japan). 


\subsection{Adsorption Experiments}

The sorption tests were carried out using a SS-304 tube with the inner diameter of $3 \mathrm{~cm}$ and $100 \mathrm{~cm}$ in length in which $70 \mathrm{~g}$ of the sorbents $(\mathrm{GAC}, \mathrm{PEI} / \mathrm{CVD} / \mathrm{GAC}$, $\mathrm{LiNO}_{3} / \mathrm{CVD} / \mathrm{GAD}$, zeolite $5 \mathrm{~A}, \mathrm{PEI} /$ zeolite $5 \mathrm{~A}$ and $\mathrm{LiNO}_{3} /$ zeolite $5 \mathrm{~A}$ ) was packed. A synthetic biogas $\left(45 \% \mathrm{CO}_{2}, 10 \% \mathrm{~N}_{2}, 45 \% \mathrm{CH}_{4}\right.$ and $\left.105 \mathrm{mg} \mathrm{dm}^{-3} \mathrm{H}_{2} \mathrm{~S}\right)$ was passed through the sorbent at the flow rate of $30.0 \mathrm{ml} \mathrm{min}^{-1}$ at room temperature. The outlet of $\mathrm{CO}_{2}$ and $\mathrm{H}_{2} \mathrm{~S}$ concentration was detected by a biogas 5000 Analyser as shown in Figure 1. The breakthrough concentration of $\mathrm{CO}_{2}$ and $\mathrm{H}_{2} \mathrm{~S}$ was defined as $50 \%$ and $10 \%$, respectively of the initial concentration. The test was stopped when the outlet $\mathrm{CO}_{2}$ and $\mathrm{H}_{2} \mathrm{~S}$ concentration reached the breakthrough concentration.

The removal efficiency can be calculated by using the Equation 1:

$$
\text { Removal efficiency }\left(\mathrm{H}_{2} \mathrm{~S} \text { or } \mathrm{CO}_{2}\right)=\left(\mathrm{C}_{0}-\mathrm{C}_{\mathrm{e}}\right) \times 100 / \mathrm{C}_{0}
$$

where $\mathrm{C}_{0}$ is the initial of $\mathrm{CO}_{2}$ or $\mathrm{H}_{2} \mathrm{~S}$ concentration, and $\mathrm{C}_{\mathrm{e}}$ is the outlet of $\mathrm{CO}_{2}$ or $\mathrm{H}_{2} \mathrm{~S}$ concentration.

The selectivity of $\mathrm{H}_{2} \mathrm{~S} / \mathrm{CH}_{4}$ and $\mathrm{CO}_{2} / \mathrm{CH}_{4}$ can be carried out by calculating the outlet gas of $\mathrm{H}_{2} \mathrm{~S} / \mathrm{CH}_{4}$ and $\mathrm{CO}_{2} / \mathrm{CH}_{4}$ by using Equations 2 and 3:

Selectivity of $\mathrm{H}_{2} \mathrm{~S} / \mathrm{CH}_{4}=$ mol outlet of $\mathrm{H}_{2} \mathrm{~S} / \mathrm{mol}$ outlet of $\mathrm{CH}_{4}$

Selectivity of $\mathrm{CO}_{2} / \mathrm{CH}_{4}=$ mol outlet of $\mathrm{CO}_{2} / \mathrm{mol}$ outlet of $\mathrm{CH}_{4}$

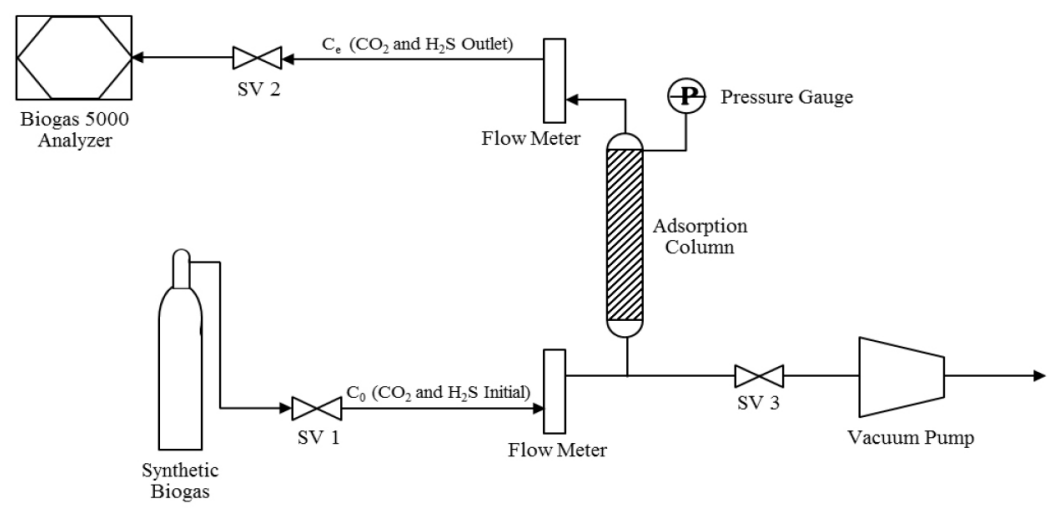

Figure 1: Schematic diagram of adsorption experiments. 


\section{RESULTS AND DISCUSSION}

\subsection{Preparation and Characterisation of Adsorbent}

SEM images of the GAC, $\mathrm{PEI} / \mathrm{CVD} / \mathrm{GAC}$, zeolite $5 \mathrm{~A}$ and $\mathrm{LiNO}_{3} /$ zeolite $5 \mathrm{~A}$ are shown in Figure 2. GAC and PEI/CVD/GAC have a rough shape, as shown in Figures 2(a) and 2(b). Zeolite $5 \mathrm{~A}$ and $\mathrm{LiNO}_{3} /$ zeolite $5 \mathrm{~A}$ have a cubic shape and size of 2-3 $\mu \mathrm{m}$ as shown in Figures 2(c) and 2(d). SEM technique was applied in order to study surface morphology of adsorbents.
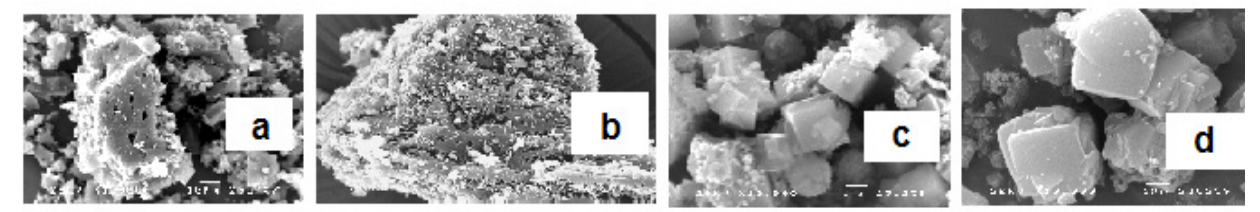

Figure 2: SEM images of (a) GAC, (b) PEI/CVD/GAC, (c) zeolite 5A and (d) $\mathrm{LiNO}_{3} /$ zeolite 5A.

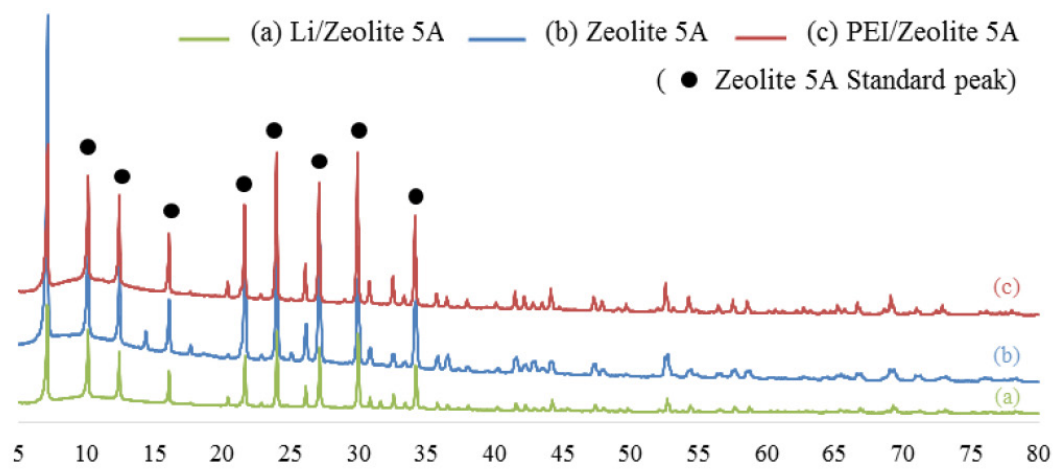

Figure 3: XRD of zeolite 5A, PEI/zeolite $5 \mathrm{~A}$ and $\mathrm{LiNO}_{3} /$ zeolite $5 \mathrm{~A}$.

The XRD pattern of zeolite $5 \mathrm{~A}, \mathrm{PEI} /$ zeolite $5 \mathrm{~A}$ and $\mathrm{LiNO}_{3} /$ zeolite $5 \mathrm{~A}$ are shown in Figure 3. The peaks of zeolite 5A, PEI/zeolite $5 \mathrm{~A}$ and $\mathrm{LiNO}_{3} /$ zeolite $5 \mathrm{~A}$ are in agreement with the standard peaks.

\subsection{Adsorption Performance}

The analytical result of the purity of methane $\left(\mathrm{CH}_{4}\right)$ in synthetic mixed biogas for $\mathrm{GAC}, \mathrm{PEI} / \mathrm{CVD} / \mathrm{GAC}, \mathrm{LiNO}_{3} / \mathrm{CVD} / \mathrm{GAC}$, zeolite $5 \mathrm{~A}, \mathrm{PEI} / 5 \mathrm{~A}$ and $\mathrm{LiNO}_{3}$ /zeolite $5 \mathrm{~A}$ were $81.53 \%, 93.6 \%, 90.8 \%, 96.6 \%, 96.8 \%$ and $97.26 \%$, respectively for the first cycle under $1 \mathrm{~atm}$. The maximum cycle of purification for synthetic biogas is seven cycles. 

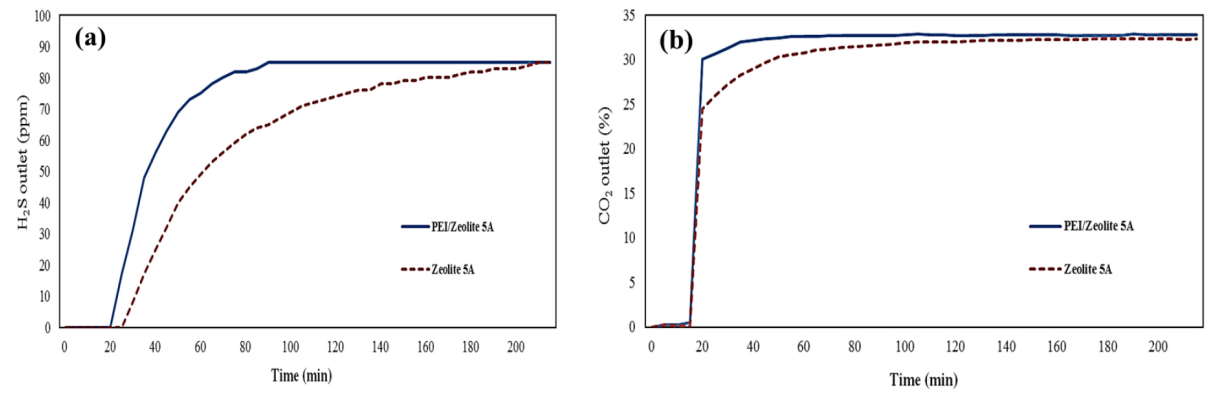

Figure 4: The concentration of (a) $\mathrm{H}_{2} \mathrm{~S}$ outlet, and (b) $\mathrm{CO}_{2}$ outlet, using various adsorbent (zeolite 5A and PEI/zeolite 5A).
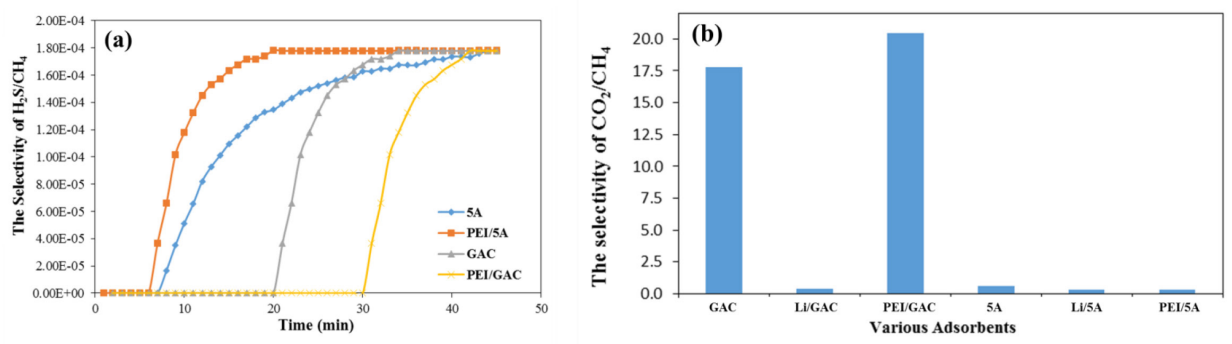

Figure 5: Images of (a) selectivity of $\mathrm{H}_{2} \mathrm{~S} / \mathrm{CH}_{4}$ by using various adsorbent (GAC, PEI/ GAC, zeolite $5 \mathrm{~A}$ and $\mathrm{PEI} /$ zeolite $5 \mathrm{~A}$ ), and (b) selectivity of $\mathrm{CO}_{2} / \mathrm{CH}_{4}$ by using various adsorbent $\left(\mathrm{GAC}, \mathrm{LiNO}_{3} / \mathrm{GAC}, \mathrm{PEI} / \mathrm{GAC}\right.$, zeolite $5 \mathrm{~A}, \mathrm{LiNO}_{3} /$ zeolite 5A and $\mathrm{PEI} /$ zeolite 5A).

The result of the $\mathrm{H}_{2} \mathrm{~S}$ and $\mathrm{CO}_{2}$ outlet concentration by using various adsorbent (zeolite 5A and PEI/zeolite 5A) are shown in Figures 4(a) and 5(a). From the results, PEI impregnated on zeolite $5 \mathrm{~A}$ which is the amine on solid adsorbent can remove the low concentration of outlet $\mathrm{H}_{2} \mathrm{~S}$. The data indicate that the impregnation process on zeolite $5 \mathrm{~A}$ can improve the adsorption efficiency. A higher PEI loading on zeolite $5 \mathrm{~A}(30 \mathrm{wt} \%)$ should enhance pore $\mathrm{H}_{2} \mathrm{~S}$ adsorption capacity, together with the decrease of surface area, pore size and pore volume of the PEIimpregnated support. The selectivity in the $\mathrm{H}_{2} \mathrm{~S} / \mathrm{CH}_{4}$ ratio of $\mathrm{PEI} / \mathrm{GAC}$ is higher than $\mathrm{PEI} /$ zeolite $5 \mathrm{~A} . \mathrm{H}_{2} \mathrm{~S}$ may have a higher affinity for $\mathrm{PEI} / \mathrm{GAC}$ because of its polarity. The selectivity of the $\mathrm{CO}_{2} / \mathrm{CH}_{4}$ ratio of $\mathrm{LiNO}_{3} / 5 \mathrm{~A}$ is higher than $\mathrm{GAC}$ as shown in Figure 5(b). The adsorbents, such as carbonaceous impregnated with PEI, will increase $\mathrm{CO}_{2}$ and $\mathrm{CH}_{4}$ adsorption capacity. While the Li-based zeolite $5 \mathrm{~A}$ is the chemical adsorbent, the strong ionic will increase the $\mathrm{CO}_{2}$ adsorption capacity. Finally, the maximum adsorption capacity of the PEI/GAC samples was $3.86 \mathrm{mmol} \mathrm{CO} / \mathrm{g}$ adsorbent. The adsorption capacity decreases when the amount of PEI is increased. The pores of adsorbent prevent $\mathrm{CO}_{2}$ from diffusing into the pores. 


\section{CONCLUSION}

The carbon molecular sieve by using PEI/impregnated on granular activated carbon by chemical vapour deposition process on granular activated carbon could improve the $\mathrm{CO}_{2}$ and $\mathrm{H}_{2} \mathrm{~S}$ adsorption efficiency. The lithium nitrate impregnated on zeolite $5 \mathrm{~A}$ is a good adsorbent for $\mathrm{CO}_{2}$ removal.

\section{ACKNOWLEDGEMENTS}

This work was carried out with the financial support from the Thailand Institute of Scientific and Technological Research (TISTR).

\section{REFERENCES}

1. Chen. Q. J. et al. (2010). Role of pore structure of activated carbon fibers in the catalytic oxidation of $\mathrm{H}_{2} \mathrm{~S}$. Ind. Eng. Chem.Res., 49, 3152-3159, https:// doi.org/10.1021/ie901223j.

2. Tian, S. et al. (2009). Enhanced removal of hydrogen sulfide from a gas stream by 3-aminopropyl terethorysilane surface functionalized activated Carbon. Adsorp., 15, 477-488, https://doi.org/10.1007/s10450-009-9198-1.

3. Wang, X. et al. (2008). Mesoporous molecular sieve supported polymer sorbents for removing $\mathrm{H}_{2} \mathrm{~S}$ from hydrogen gas streams. Top. Catal., 49, 108-117, https://doi.org/10.1007/s11244-008-9072-5.

4. Wang, R. (2003). Investigation on a new liquid redox method for $\mathrm{H}_{2} \mathrm{~S}$ removal and sulfur recovery with heteropoly compound. Sep. Purif. Technol., 31(1), 111-121, https://doi.org/10.1016/S1383-5866(02)00153-3.

5. Zhang, Z. J. et al. (2010). Adsorption of $\mathrm{CO}_{2}$ on zeolite $13 \mathrm{X}$ and activated carbon with higher surface. Sep. Sci. Technol., 45, 710-719, https://doi. org/10.1080/01496390903571192.

6. Anuwattana, R., Patkool, C. \& Chavakitchareon, P. $\mathrm{CO}_{2}$ adsorption using activated carbon via chemical vapor deposition process. Eng. J., 20(4), 5968.

7. Sayari A., Belmabkhout, Y. \& Serna-Guerrero, R. (2011). Flue gas treatment via $\mathrm{CO}_{2}$ adsorption. Chem. Eng. J., 171(3), 760-774, https://doi. org/10.1016/j.cej.2011.02.007.

8. Wang, X. et al. (2009). Infrared study of $\mathrm{CO}_{2}$ sorption over "molecular basket" sorbent consisting of polyethylenimine modified mesoporous molecular sieve. J. Phys. Chem. C, 113(17), 7260-7268, https://doi. org/10.1021/jp809946y. 
9. Yong, H. et al. (2008). Breakthrough characteristics of reformate desulfurization using $\mathrm{ZnO}$ sorbents for logistic fuel cell power systems. Ind. Eng. Chem. Res., 47(24), 10064-10070, https://doi.org/10.1021/ie8008617.

10. Polychronopoulou, K. et al. (2005). Novel Fe-Mn-Zn-Ti-O mixedmetal oxides for the low-temperature removal of $\mathrm{H}_{2} \mathrm{~S}$ from gas streams in the presence of $\mathrm{H}_{2}, \mathrm{CO}_{2}$, and $\mathrm{H}_{2} \mathrm{O} . J$. Catal., 236, 205-220, https://doi. org/10.1016/j.jcat.2005.10.001.

11. Abbasian, J. \& Slimane, R. B. (1998). A regenerable copper-based for $\mathrm{H}_{2} \mathrm{~S}$ removal from coal gases. Ind. Eng. Chem. Res., 37, 2775-2782, https://doi. org/10.1021/ie980047h. 